\title{
Legislative Initiative of Citizens in Romania and at the European Level
}

\author{
Camelia Florentina Stoica \\ MARIETA SAFTA
}

\begin{abstract}
The citizens' initiative right enables them to directly participate in the law-making process. Issues of great social importance can thus be brought to the attention of the ordinary legislator who is called to embed into a normative content the will of those whom it represents. The importance of the citizens' initiative right for the strengthening of democracy led to its enshrining into States' Constitutions, as well as its stipulation into EU regulations. Nonetheless, even though, in theory, the citizens' initiative right represents a basic element in terms of participation of the people in the democratic decision-making process, in practice, the purpose of the regulation has not been reached. Thus, the citizens' initiative right is rarely exercised, also because of a lack of information on its utility, significance and mechanisms. Based on these realities, within this study, we shall carry out an examination of the regulations concerning citizens' legislative initiative in Romanian law and at the European level, for the purpose of highlighting the elements characterising this right and to promote it as a real democratic exercise, not only considering it as a generous theoretical construction.
\end{abstract}

Keywords: democracy, legislative initiative, the Constitutional Court, the European Union

\section{INTRODUCTION}

The legislative initiative is the starting point in the development of legislation and it is, therefore, an indicator of real democracy. Of course, what matters, from this perspective, are both the scope of subjects of law entitled to initiate a law and the importance paid by the debate forum to these initiatives, according to the subjects that promote them.

The citizens' initiative right represents an opportunity for citizens to be actively involved in the legislative process, from the first phase of the process and, therefore, is an important democratic tool. In consideration of this role, the citizens' initiative right is regulated in the Constitutions of States, as well as at the European Union level.

In what follows, we shall examine this regulation, at a national level (constitutional and infra-constitutional) and supranational level, to identify commonalities, as well as differences, which can give rise to ideas that improve the current national legislative framework, so that the right may go beyond the stage of theoretical construction and serve the real purpose for which it was established.

Camelia Florentina Stoica, Professor, Ph.D., Head of Law Department, Bucharest University of Economic Studies. E-mail: cameliastoica@cig.ase.ro

Marieta Safta, Associate lecturer, Ph.D., Law Department, Bucharest University of Economic Studies, First assistant magistrate to the Constitutional Court of Romania. E-mail: marietasafta@, yahoo.com

(Received: 29.01.2014; revision received: 30.03.2014; accepted: 06.04.2014.) 


\section{RULES ON THE CITIZENS' INITIATIVE RIGHT ESTABLISHED AT THE NATIONAL LEVEL}

\section{Constitutional rules}

The citizens' initiative right is regulated by the Constitution of Romania under Article 74 Legislative initiative and Article 150 - Initiative of revision (Constitution).

These texts lay down conditions governing the exercise of this right, as follows:

- a minimum number of citizens entitled to vote (100.000 for organic and ordinary laws, respectively 500.000 for constitutional laws);

- territorial dispersion of citizens exercising this right (for organic and ordinary laws: the citizens who put into action their right to initiate legislation must belong to at least one quarter of the Country's counties, while, in each of these counties or in the Municipality of Bucharest, at least 5,000 signatures should be registered in support of such an initiative; for constitutional laws: the citizens who initiate a revision of the Constitution must belong to at least half the number of the counties in the country, and in each of these counties or in the Municipality of Bucharest, at least 20,000 signatures must be recorded in support of such an initiative);

- limits: as concerns organic and ordinary laws, a citizens' legislative initiative may not touch on matters concerning taxation, international affairs, amnesty or pardons; as concerns constitutional laws, the limits applicable to any initiative for revision, as regulated by Article 152 of the Constitution, include the national, independent, unitary and indivisible character of the Romanian State, the Republican form of government, or territorial integrity, independence of judiciary, political pluralism, or the official language, any revision that leads to the suppression of any of the citizens' fundamental rights and freedoms, or their safeguards.

Establishing a minimum number of citizens and territorial dispersion is necessary to ensure representativeness and certainty that the legislative proposal reflects a general interest. As concerns the special restrictions imposed by Article 74 (2) of the Constitution, it was pointed out (Muraru-Tănăsescu 2008: 706) that "they are imposed by virtue of the fact that they concern general problems of State governance and that they could affect general interests in the law-making process, by promoting the interests of a small group of citizens entitled to vote at the expense of an electoral body that promoted a parliamentary majority and a legislative program that can be vitiated by legal authorization of a particular legal system".

Similar conditions are also imposed in the Constitutions of other States regarding the right to legislative initiative. Thus, as concerns the minimum number of citizens entitled to vote which is needed to be met in order to initiate legislation, it varies, i.e.: 1000 Lichtenstein, 5000 - Slovenia, 10.000 - Macedonia, 20.000 - Albania, 30.000 - Georgia, 50.000 - Lithuania, Italy, 100000 - Poland, 500000 - Spain, one tenth of the electorate Andorra, Latvia (Nussberger 2010). Linked to the idea of representation, the number is of course directly proportional to the population of each country. There are also limits on the exercise of this right. We mention the example of Spain, in consideration of the similarity to the regulation in Romania; the Spanish Constitution restricts the citizens' initiative right excluding from its scope the organic laws, which establish matters related to taxes, international affairs, amnesty and pardons (Bartole-Nussberger-Hegelson 2008).

In order to establish the constitutional framework of the citizens' initiative right, the texts of Article 74 and Article 150 of the Constitution of Romania must be taken in 
conjunction with those of Article $146 \mathrm{j}$ ), stating that one of the powers of the Constitutional Court is to verify whether conditions are met for the citizens' exercise of their legislative initiative (Deleanu 2006: 885).

The rules laid down by the Constitution are developed by infra-constitutional laws.

\section{Infra-constitutional rules}

Law no. $189 / 1999$ on the exercise of the legislative initiative by citizens ${ }^{1}$ regulates in detail the conditions regarding the exercise of this right by citizens.

Thus:

- the legislative initiative of citizens is exercised by a legislative proposal (Article 1 of Law);

- legislation is initiated by an initiative committee composed of 10 citizens eligible to vote; this committee cannot consist of people elected by universal suffrage, members of the Government, people appointed by the Prime Minister or those who, according to the law, cannot be members of political parties; the composition of the initiative committee shall be brought to public knowledge, together with the legislative proposal that is the object of the initiative, through publication in the Official Gazette of Romania, Part I; the initiative committee is the body that represents the citizens - who support the legislative proposal and ensures registration of the legislative proposal with the competent Chamber of the Parliament, within 6 months from the date of publication thereof (Article 2 of the Law);

- the legislative proposal shall be drawn up in the form required for bills and, in view of publication, it shall be endorsed in advance by the Legislative Council (Article 3 of the Law);

- the published legislative proposal shall be promoted based on the citizens' assent thereto, i.e. signing the lists of supporters (Article 4 (1) of the law);

- the lists of supporters shall be prepared in compliance with the administrativeterritorial organisation of the country and shall include: the name of the legislative proposal subject to the initiative and the Official Gazette in which it was published, the county and the locality in which the supporters reside; the last name(s), first name(s) and addresses of supporters, the voter cards, for those who possess them, the identity cards and personal identification codes; the signatures of supporters; the district (for the municipality of Bucharest). Any delegation or representation for signing the list of supporters is forbidden (Article 4 (2) and (3) of the law);

- the lists of supporters forms shall be printed on paper sheets, A4 format, removable and numbered. The forms shall be printed on one side of the sheet and shall include the provisions in par. (2) except those concerning supporters, which shall be completed in handwritten form, when they sign the list; each printed page of the list of supporters shall be signed by an initiative committee member or another person authorized in writing by the committee to draw up the list. The authorized person must be one of the supporters; (Article 4 (5) and (6) of the Law);

- the lists of supporters must be certified by the mayor of the locality, either personally or, in urban areas, through the Mayor's Office staff, specifically authorised by the mayor for this purpose. Certification concerns the capacity of citizens entitled to vote and the residence of the supporters and is carried out by checking the lists of supporters, and in terms of residence, it is done in collaboration with the respective local police authority, if necessary;

${ }^{1}$ Republished in the Official Gazette of Romania, Part I, no. 516 of 8 June 2004. 
for certification, the lists of supporters are submitted to the Mayor's Office; any interested person may inspect the file and may contest the signature or other provision contained in the lists (Article 5 (1) and (2) of the Law);

- certification by the mayor of the list of supporters shall be made no later than 15 days from registration of the file with the Mayor's Office, through the signature of the person who carried out the verification, indicating the power of attorney, if any, and the date when the certification took place, being stamped. If the mayor has requested the support of the local police authority, the latter's representative shall sign also, specifying the aspects checked. The signature shall be applied on the back cover of the file containing the lists checked, which are kept by the initiative committee, after being confronted with the file submitted to the Mayor's Office. Non-certified data shall be removed from the list;

- the legislative proposal that constitutes the object of the citizens' initiative, together with the explanatory memorandum and the files containing the lists of supporters, shall be registered with the Chamber of Parliament to which it was presented, upon request signed by the members of the initiative committee. The request shall include the power of attorney granted to 5 members at the most, who would represent the initiative committee in view of promoting and supporting the initiative after registration (Article 6 (1) of the Law);

- the Constitutional Court, ex officio (in case of legislative initiatives for revision of the Constitution) or upon notification from the president of the Chamber of Parliament where the initiative was registered (in case of legislative initiatives concerning organic or ordinary laws), shall verify:

a) the constitutional nature of the legislative proposal that is the object of the initiative;

b) compliance with the requirements concerning the publication of the proposals and whether the lists of supporters submitted are certified pursuant to Article 5;

c) compliance with the minimum number of supporters to promote the initiative referred to in Article 73 and, where appropriate, Article 146 of the Constitution - as well as the territorial dispersion in the counties and Municipality of Bucharest, provided by the same articles.

The Constitutional Court shall decide within 30 days from notification on the legislative proposal and within 60 days from notification on the proposal for revision of the Constitution and the decision or, as the case may be, the ruling of the Constitutional Court shall be communicated to the president of the Chamber of Parliament that made the notification and it shall be published in the Official Gazette of Romania, Part I (Article 7 (1 to 4) of the Law).

- upon receiving the ruling of the Constitutional Court, the Chamber of Parliament referred to in connection with the legislative initiative shall start the parliamentary lawmaking procedure (Article 7 (5) of the Law). This, of course, occurs when the ruling has ascertained compliance with the requirements for exercising the citizens' initiative, otherwise, the ruling/decision of the Court stops the legislative process in the phase of parliamentary debates (Vida 2011: 131).

Completion of this procedure does not guarantee adoption of a law, but only initiation of the law-making procedure, resulting in either adoption or not of the law that constitutes the object of the proposal submitted by citizens.

The infra-constitutional framework is completed by the relevant provisions of Articles 48 and 49 of Law no. 47/1992 on the organisation and functioning of the Constitutional Court regarding the verification of the conditions for the exercise of the legislative initiative by citizens. 
One can note the strict nature of time limits, as well as the numerous formalities that need to be carried out in order to initiate legislation, as well as the broad scope of authorities involved in this process: the Legislative Council, which needs to endorse the legislative proposals, mayors and police bodies, which need to certify the lists of supporters, the Constitutional Court, which needs to verify whether conditions are met for the citizens' exercise of their legislative initiative. This procedure is certainly understandable, given the need for legal certainty regarding willingness to exercise initiative. At the same time, its cumbersome nature is likely to discourage those who wish to exercise this right. In any case, it is worth stressing the high responsibility of the authorities involved in the procedure, especially that of the mayors, whereas the lack of proper certification may entitle the Constitutional Court to establish the non-observance of the conditions for the citizens' exercise of their legislative initiative, so that the procedure would be stopped - i.e. the legislative proposal would not be subject to parliamentary debates - due to the fault of one of the authorities. At the same time, it is, of course, the responsibility of the initiative committee to ensure and recognize potential violations that could lead to a rejection of the initiative on procedural grounds.

\section{EU RULES ON THE CITIZENS' INITIATIVE RIGHT}

Article 11 (4) of the Treaty on European Union² regulates the EU citizens' initiative right, establishing, similarly to existing national regulations, the requirements that would certify its representativeness, developed together with the procedure relating to the exercise of the citizens' initiative right, laid out in Regulation no. 211/2011 of the European Parliament and the Council of 16 February 2011 on the citizens' initiative. ${ }^{3}$

The rules and requirements are, in essence, as follows:

- the initiative must be supported by one million Union citizens, who must be of the age that is entitled to vote in elections regarding the European Parliament, and who must come from at least one quarter of all Member States;

- the organisers shall form a citizens' committee of at least seven people who are residents of at least seven different Member States, and shall designate one representative and one substitute, who shall liaise between the citizens' committee and the institutions of the Union throughout the procedure and be mandated to speak and act on behalf of the citizens' committee;

- prior to initiating the collection of statements of support from signatories for a proposed citizens' initiative, the organisers shall be required to register it with the Commission, providing the information set out in Annex II to the Regulation (including the title of the proposed citizens' initiative, in no more than 100 characters, the subject matter, in no more than 200 characters, a description of the objectives of the proposed citizens' initiative on which the Commission is invited to act, in no more than 500 characters, the provisions of the Treaties considered relevant by the organisers for the proposed action, the full names, postal addresses, nationalities and dates of birth of the seven members of the citizens' committee, indicating specifically the representative and substitute as well as their e-mail addresses, all sources of support and funding for the proposed citizens' initiative at the time of registration), in one of the official languages of the Union;

\footnotetext{
2 http://eur-lex.europa.eu/LexUriServ/LexUriServ.do?uri=OJ:C:2010:083:0013:0046:EN:PDF

3 Official Journal of the European Union L65/1 of 11 March 2011.
} 
- within two months of receipt of the information set out above, the Commission shall register a proposed citizens' initiative under a unique registration number and send a confirmation to the organisers, provided that the following conditions are fulfilled: the citizens' committee has been formed and the contact people have been designated; the proposed citizens' initiative does not manifestly fall outside the framework of the Commission's powers to submit a proposal relating to a legal act of the Union for the purpose of implementing the Treaties; the proposed citizens' initiative is not manifestly abusive, frivolous or vexatious; and the proposed citizens' initiative is not manifestly contrary to the values of the Union; the Commission shall refuse the registration if these conditions are not met and shall inform the organisers about the reasons for such refusal and all possible judicial and extrajudicial remedies available to them;

- the organisers may collect statements of support in paper form or electronically; where statements of support are collected online, the advanced electronic signature shall be used, within the meaning of Directive 1999/93/EC of the European Parliament and of the Council of 13 December 1999 on a Community framework for electronic signatures;

- the statement of support forms made available by the organisers shall indicate only the personal data that is required for the purposes of verification by the Member States and shall be collected after the date of registration of the proposed citizens' initiative within a period not exceeding 12 months; Article 6 of the Regulation establishes the rules concerning the online collection of statements of support;

- after collecting the necessary statements of support, the organisers shall submit the statements of support, in paper or electronic form, to the relevant competent authorities referred to in Article 15 which, within a period not exceeding three months from receipt of the request, shall verify them and deliver to the organisers a certificate concerning the number of valid statements of support for the Member State concerned;

- after obtaining the certificates, the organisers may submit the citizens' initiative to the Commission, accompanied by information regarding any support and funding received for that initiative. That information shall be published in the register;

- the Commission publishes the initiative in the register, receives the organisers at an appropriate level to allow them to explain in detail the matters raised by the citizens' initiative and, within three months, sets out in a brief its legal and political conclusions on the citizens' initiative, the action it intends to take, if any, and its reasons for taking or not taking that action;

- where the conditions are fulfilled, the organisers shall be given an opportunity to present the citizens' initiative at a public hearing at the European Parliament.

There are a number of factors likely to facilitate the exercise of the legislative initiative, namely: collection of statements of support in electronic form, empowerment of the authorities of the Member States in the process of verifying statements of support (the authorities being required to perform this verification and issue a certificate with their findings), specific regulation of the possibility of public support for the initiative at the European Parliament (a possibility which, in our view, increases the chances of success for such an initiative, i.e. adoption of a piece of legislation). 


\section{CONSIDERATIONS ON THE CURRENT RULES PERTAINING TO THE RIGHT OF LEGISLATIVE INITIATIVE WITH REFERENCE TO THE RELEVANT CASE LAW OF THE CONSTITUTIONAL COURT OF ROMANIA}

The rather cumbersome procedure and lack of adequate information on the citizens' initiative right in Romania resulted in a small number of such initiatives.

Having examined the case-law of the Constitutional Court on this matter, we note that, although the citizens' initiative right was enshrined in the 1991 Constitution, only 7 legislative initiatives have been submitted for constitutional review since then. On this matter, the Court delivered $6^{4}$ rulings and one decision: Rulings nos. 1 and 2 of 27 July 1995 on the legislative initiative regarding the draft law on education in minority languages, ${ }^{5}$ no. 1 of 16 April 1997 on citizens' legislative initiative regarding the amendment of Article 9 (1) of Education Law no. 84/1995, ${ }^{6}$ no. 1 of 30 June 2004 on citizens' legislative initiative regarding the amendment of Article 170 of Education Law no. 84/1995, republished, as subsequently amended, ${ }^{7}$ no. 6 of 4 July 2007 on citizens' legislative initiative regarding the revision of the Constitution of Romania ${ }^{8}$ and no.38 of 3 December 2009 on citizens' legislative initiative regarding the legislative proposal entitled the Law on mandatory minimum annual funding level for financing health, ${ }^{9}$ as well as Decision no. 82 of 27 April $2000 .^{10}$

Thus, through the Ruling of the Plenum of the Constitutional Court no. 1 of 27 July 1995 on the draft law regarding education in minority languages and the Ruling of the Plenum of the Constitutional Court no. 2 of 27 July 1995 on the draft law concerning the employees' mutual benefit fund, the Court examined the legislative initiative in relation to the provisions of Article 73 (1), (2) and (4) of the Constitution, stating that "in the absence of a law that would regulate the exercise of the citizens' initiative right [...] the Constitutional Court cannot verify whether the legislative initiative on which it was notified belongs exclusively to citizens entitled to vote. Such verification would require certification in respect of both the authenticity of the signatures on the lists and the fact that the signatories are citizens entitled to vote. Where there is a lack of such certification, the verification cannot be carried out". The same conclusion appears also in the Ruling of the Plenum of the Constitutional Court no. 1 of 16 April 1997 on the legislative initiative for amendment of Article 9 (1) of the Education Law no. 84/1995, because, despite the fact that almost two years had passed between the aforementioned rulings, no law on the right to legislative initiative had yet been enacted.

The legislator's passivity ${ }^{11}$ could not impede the exercise of a constitutional right given that the relevant constitutional rules could be directly applied, as the Court established

${ }^{4}$ www.ccr.ro - Periodical statistics.

5 Published in the Official Gazette of Romania, Part I, no. 172 of 3 August 1995.

${ }^{6}$ Ibid. no. 82 of 6 May 1997.

7 Ibid. no. 660 of 6 July 2004.

8 Ibid. no. 540 of 8 August 2007.

9 Ibid. no. 880 of 16 December 2009.

10 Ibid. no. 193 of 4 May 2000.

11 Because, as highlighted in the specialized literature (Vida 2012: 160) "In fact, this form of legislative initiative is conditional on the adoption of a law on the matter. Although, formally, the Constitution of Romania does not set a requirement concerning the existence of laws regulating the exercise of popular initiative, this requirement results, indirectly, from the provisions of Article $146 j$ ) 
in the reasoning part of its rulings. The Constitutional Court found that, according to the documents submitted, the legislative initiatives met the formal requirements set forth in Article 73 (1), (2) and (4) of the Constitution, and the lack of a special regulation "cannot result in citizens' inability to exercise their right to legislative initiative, given that the constitutional provisions of Article 73 (1) are not conditional on the existence of further enactments, on the contrary, they are directly applicable".

Similarly, through Decision no. 82 of 27 April 2000 on the constitutionality of the legislative initiative for revision of the provisions of Article 41 (2) first sentence of the Constitution, the Court held that "in the absence of a law regulating the exercise of the citizens' initiative right, concerning a law in force during the period in which the lists of supporters were prepared, signed and certified, the authenticity of signatures on the lists, the signatories' capacity as citizens entitled to vote or their territorial dispersion cannot be verified, so as to decide on compliance with the conditions laid down in Article 146 of the Constitution". The Court stressed that "the absence of a law in force in the period in which the lists of supporters were prepared, signed and certified may restrict the exercise of citizens' constitutional right to initiate legislative proposals, including the revision of the Constitution, the provisions of Article 146 thereof being directly applicable".

In other words, it is not about a refusal by the Constitutional Court to exercise one of its powers, ${ }^{12}$ or about the legislative initiative's failure to meet the conditions stipulated by the Constitution, but simply an observation about the lack of a legislative framework that would regulate the verification of lists of supporters, without thus preventing the exercise of the constitutional right.

As concerns the other three cases: through Ruling no. 1 of 30 June 2004, the Constitutional Court stated that "the legislative proposal that constitutes the object of the citizens' initiative for the amendment and completion of Article 170 of the Education Law no. 84/1995, republished, with subsequent amendments, fulfils the requirements of Article 74 (1) and (2) of the Constitution, republished, as well as those of Law no. 189/1999 on the exercise of legislative initiative by citizens, republished"; through Ruling no. 6 of 4 July 2007, it stated that the "citizens' legislative initiative for revision of the Constitution of Romania, in terms of Article 48, published in the Official Gazette of Romania, Part I, no. 536 of 21 June 2006, does not meet the requirements of Article 150 of the Constitution" and through Ruling no. 38 of 3 December 2009, it stated that the 'citizens' legislative initiative on the legislative proposal entitled "Law on the minimum annual funds required to finance health" does not meet the requirements of Article 74 (1) of the Constitution'.

In the last two rulings mentioned above, we note, mainly, non-compliance with the requirement on territorial dispersion provided by Article 150 and, respectively, Article 74 of the Constitution, and, having read the reasoning part substantiating them, we note that they highlight also misapplication of the law, which draws attention to the need for greater accountability of both public authorities involved in the citizens' initiative procedure, and the initiative committee.

Thus, for example, through Ruling no. 6/2007, the Court held that "there are cases where the lists of supporters were not certified, as in the case of the Municipality of Timişoara or the 4 districts of the Municipality of Bucharest.[...] Certification of the lists of

based on which the Constitutional Court verifies whether conditions are met for the citizens'exercise of their legislative initiative".

12 For a different opinion, see Valea 2012: 35-40. 
supporters was not carried out, in all cases, in compliance with the provisions of Article 5 of Law no. 189/1999, republished, by the mayors of administrative-territorial units or, in urban areas, by the Mayor's Office staff authorised by the mayor for this purpose. Thus, there were cases where certification of the capacity as citizens entitled to vote and the supporters' residence, [...] was done based on a mere signature, in the rural area, without mentioning the capacity as mayor, bearing the stamp of the local council and not that of the mayor, or cases where the certification was done by the secretary of the local council. Taking into account the provisions of Article 5 (1) of the same law, in urban areas, the certification is valid only if done by the mayor, given that he/she is not entitled to authorise officers of the local authority to certify the capacity as citizens entitled to vote or the residence of the initiatives'signatories. These certifications are deemed illegal; therefore, they are not included in the total number of certifications, according to the particulars in the summary lists of adhesions in the county".

Also in case of Ruling no. 38/2009, the Court found that "certification of lists of supporters was not done in all cases in strict compliance with the provisions of Article 5 of Law no. 189/1999, republished, by the mayors of administrative-territorial units or, in urban areas, by the Mayor's Office staff authorised by the mayor for this purpose. Thus, there were situations where, in rural areas, certification of the capacity of citizens entitled to vote and the supporters' residence, referred to in Article 5 of Law no. 189/1999, republished, was done based on a mere signature, without mentioning the capacity of the person who signed, bearing the stamp of the local council and not that of the mayor, and cases where the lists of supporters bore only the stamp of the Mayor's Office, with no signature, as well as cases where the certification was done by either the secretary of the village, "on behalf of" the mayor, or an employee following an order of the mayor. There were also cases where, in urban areas, the certification was done by a signature, without mentioning the capacity of the person who signed, and bearing the stamp of the local council, as well as a case where the certification was done as a result of "random" verification of only some of the signatures in the 3rd district of Bucharest. Given these findings, the Court states that these supporters, certified in breach of Article 5 of Law no. 189/1999, republished, may not be included in the total number of supporters of the legislative proposal, whose certification is legal".

It is obvious that the "removal" of supporters who are not validly certified has direct effects on compliance with the conditions laid down by the Constitution, reducing the total number of supporters, respectively those at the level of a county / district, below the limit set by the Constitution, resulting in a consequential failure to comply with conditions for the exercise of legislative initiative. As a result, strict adherence to the law by public authorities competent in the field is necessary.

At the European level, there were citizens' initiatives on EU legislation in the fields of environment and energy, responsible waste management, common educational goals, stopping animal testing, voting rights for EU citizens living in other Member States, protecting human embryos in research and public health, access to water, roaming fees, increased mobility (the legislative initiative concerning access to water ${ }^{13}$ has already collected more than one million signatures, and the "One of Us" initiative has collected one

$13 \mathrm{http} / /$ www.right 2 water.eu/news/first-european-citizens $\% \mathrm{E} 2 \% 80 \% 99$-initiative-collectsalmost-2-million-signatures-across-europe 
million signatures ${ }^{14}$ ). The short time that has elapsed since it was regulated in the Treaty on European Union and then in Regulation no. 211/2011 of the European Parliament and of the Council was not sufficient for obtaining relevant experience on the matter.

\section{CONCLUSIONS AND DE LEGE FERENDA PROPOSALS}

Given that, over more than 20 years, only 7 citizens' initiatives have completed the procedure required in order to be submitted for verification to the Constitutional Court, where some of them have been found as failing to satisfy the conditions laid down by the Constitution, we are entitled to draw the conclusion that the citizen's initiative right is ineffective (Poggi 2002). ${ }^{15}$

To occupy its position as a democratic exercise, as is recognized at the European level, implies, on the one hand, quality of information, civic education and responsibility, and on the other hand, an improvement in the current legislative framework.

In terms of lege ferenda proposals, we deem necessary an approximation of national legislation with the relevant European legislation, particularly with respect to the following:

- collection of statements of support both in paper and electronic formats;

- empowerment of public authorities carrying out certification of lists of supporters, establishing, according to the European model, the obligation to issue a certificate regarding the number of valid statements of support for the respective county / sector; this would simplify the procedure carried out by the Constitutional Court which, currently, involves verification of all lists of supporters in terms of compliance with the certification procedure;

- specifically regulate, within the relevant framework instrument, the hearing at Parliament of the citizens' representatives forming the initiative committee, in order to explain and support the legislative initiative; this would popularize - even via the massmedia - citizens' initiatives, raising awareness for this democratic instrument. ${ }^{16}$

The approximation to which we have referred could also achieve a correlation of national legislation with the one existing at the European level, in the sense of also regulating within the same instrument the conditions to be provided at the national level in order to exercise citizens' initiative right at the European level. ${ }^{17}$

$14 \mathrm{http}: / / w w w . o n e o f u s . e u / r o /$ initiativa-legislativa-cetateneasca-europeana-unul-dintre-noi-astrans-mai-mult-de-un-milion-de-semnaturi-din-toata-europa/

15 For similar conclusions, in Italy see Poggi 2002.

16 See, for example, in terms of public impact and force of the strong support for such an initiative, the legislative initiative on mortgage, supported by 1.5 million Spanish citizens - http:// www.eapn.eu/en/news-and-publications/news/eapn-national-networks-news/the-people-s-legislativeinitiative-on-mortgage-

17 For example, Latvia - Law on National Referendums, Legislative Initiatives and the European Citizens' Initiative; http://cvk.lv/pub/public/28862.html - the title of the law was amended on 20 September 2012. 


\section{REFERENCES}

Bartole, S. - Nussberger, A. - Hegelson M. (2008): “Report on legislative initiative”, adopted by the Venice Commissionat the 77th Plenary Session, Venice, 12-13 December 2008, www.venice.coe. int.

Constitutional Court Decision no. 82/2000, published in the Official Gazette of Romania, Part I, no. 193 of 4 May 2000;

Constitutional Court Ruling no. 1/1995, published in the Official Gazette of Romania, Part I, no. 172 of 3 August 1995;

Constitutional Court Ruling no. 1/1997, published in the Official Gazette of Romania, Part I, no. 82 of 6 May 1997;

Constitutional Court Ruling no. 1/2004, published in the Official Gazette of Romania, Part I, no. 660 of 6 July 2004;

Constitutional Court Ruling no. 2/1995, published in the Official Gazette of Romania, Part I, no. 172 of 3 August 1995;

Constitutional Court Ruling no. 38/2009, published in the Official Gazette of Romania, Part I, no. 880 of 16 December 2009;

Constitutional Court Ruling no. 6/2007, published in the Official Gazette of Romania, Part I, no. 540 of 8 August 2007;

Deleanu, I. (2006): Constitutional Institutions and Procedures, in Romanian Law and Comparative Law. Bucharest: C. H. Beck, 885.

Law no. 189/1999, republished in the Official Gazette of Romania, Part I, no. 516 of 8 June 2004;

Muraru, I. - Tănăsescu, E. S. (2008): Constituția României - comentarii pe articole (Constitution of Romania - Comments on articles). Bucharest: C. H. Beck, 706.

Nussberger, A. (2010): Report "Constitutional holders of legislative initiative: a general overview" CDL-UTD (2010) 019, www.venice.coe.int

Poggi, A. M. (2002): Legislative initiative and popular participation in the 1948 Constitution and its transposition in the first generation, Perspectives on Federalism, 4(1), 2002.

Treaty on the functioning of the European Union, published in the Official Journal of the European Union L65/1 of 11 March 2011.

Valea, D. C. (2012): Constitutional review of citizens' initiatives in Romania. Juridical Current Journal, 1: 35-40.

Vida, I. (2011): Constitutional Court of Romania, judicial politics or political justice? Bucharest: Monitorul Oficial, 131.

Vida, I. (2012): Formal legistics. Introduction in the legislative technique and procedure. Bucharest: Universul Juridic, 160. 